\title{
ОРГАНІЗАЦІЙНІ АСПЕКТИ ФОРМУВАННЯ ЗВІТУ ПРО УПРАВЛІННЯ
}

\section{Ковальова Т.В. канд. екон. наук, доцент}

Харківський національний автомобільно-дорожній університет

Постановка проблеми та їі зв'язок із практичними завданнями. Бухгалтерський облік, як складова системи управління підприємства, забезпечує менеджерів інформацією для його ефективного управління. 3 іншого боку, інформація, що сформована на підприємстві стає у нагоді стороннім користувачам, на підставі якої вони роблять висновки щодо стану та перспектив його розвитку. Результатом узагальнення інформації на підприємстві є звітність, на підставі якої якраз і роблять ці висновки. Звітність підприємства за 2018p. розширилась завдяки появі нової форми: Звіту про управління. Поява цієї форми викликала серед керівників та бухгалтерівпрактиків деякі труднощі щодо організації складання, оскільки, вона вимагає від них уміння не тільки обробляти, вже звиклу для них інформацію, а й працювати дещо в іншому руслі - оцінювати сучасну діяльність підприємства $\mathrm{i}$ робити прогнози на майбутнє. Хоча, безумовно, в умовах нестабільної економіки, жорсткої конкуренції та за умов ризиків та невизначеності, цей звіт забезпечить державні органи інформацією, що необхідна для прогнозування розвитку економіки в цілому. Крім того, інформація викладена у звіті дасть можливість управлінцям забезпечити ефективність стратегічного розвитку підприємства.

Аналіз останніх досліджень та публікацій. Зараз можна говорити про незначну кількість публікацій за вказаною темою дослідження. Питаннями, які відносяться до Звіту про управління цікавились: Т. Бондар [1], К. Безверхий [2] та В. Пантелеєв [2], А. Хомюк [3]. Ці автори вели мову про структуру звіту, наповнення його складових та порівнювали його із закордонними аналогами, розглядали концептуальні основи консолідованого звіту. К.Безверхий проводить порівняльний аналіз елементів структури інтегрованої звітності та звіту про управління 3 метою виявлення їх відмінностей і доцільності їх одночасного застосування у вітчизняній практиці звітування [4]. Інша група науковців, у складі:, Ю.Байрактар [5], Р.Мацьків [6], І.Жураковська [7], у своїх роботах звертали увагу на нефінансову звітність, іiї структуру та особливості складання. С. Рогозний та А.Озеран вказують на термінологічні неузгодженості між різними нормативними актами України. Зокрема, Закон про бух облік передбачає складання звіту про управління, а Закон про цінні папери вимагає складати звіт керівництва як складову частину річної та проміжної інформації про емітента. По суті йдеться про один i той самий звіт, який повинен відображати думку керівництва про стан i розвиток підприємства, але неузгодженість у термінах необхідно усунути якнайшвидше [8]. В.Онищенко [9] вважає, що звіт з управління є не бухгалтерським, на відміну від А. Озеран [10], яка навпаки, вважає цю форму частиною фінансової звітності. 
Д.О.Калітенко, говорить про таксономію форм звітності, в тому числі і звіту про управління [11] Розмаїття точок зору щодо цієї форми звіту підтверджують необхідність його детального вивчення, особливо в частині організації складання.

Невирішені складові загальної проблеми. Відомо, що процедура складання фінансової звітності нерозривно пов'язана із системою бухгалтерського обліку, оскільки є завершальною ланкою у технології облікового процесу. Фінансова звітність базується на даних первинного, аналітичного та синтетичного обліку, тоді як для складання звіту про управління, ця інформація не потрібна. Звіт про управління не є складовою фінансової звітності, а отже і формування його дещо інше.Відсутність єдиної концепції формування звіту про управління обумовлена недостатніми дослідженнями окремих положень організаційного характеру, a ïx неузгодженістю з методичними аспектами, обмежує якість і прозорість цієї форми. Необхідність розв'язання цих проблем підкреслює актуальність дослідження та націлює на досягнення вищого рівня інформативності та зрозумілості звіту про управління.

Формулювання цілей статі. Метою дослідження $є$ інформаційна репрезентація певних моментів організації складання Звіту про управління задля забезпечення користувачів достовірною інформацією.

Виклад основного матеріалу дослідження. Середовище формування звіту про управління направленні, як правило, на методичну сторону питання, однак, проблема цієї форми звітності, насправді, є багатогранною і торкається не лише методики, а й організації процесу. У кінці 2017 р. Верховною Радою був прийнятий Закон «Про внесення змін до Закону України «Про бухгалтерський облік та фінансову звітність в Україні» (щодо удосконалення деяких положень)», який і затвердив необхідність складати Звіт з управління документ, що містить фінансову та нефінансову інформацію, яка характеризує стан і перспективи розвитку підприємства та розкриває основні ризики i невизначеності його діяльності [12]. Таким чином Україна виконала Директиву 2013/34/ЄC і 2014/95/ЄС Європейського Парламенту та Ради. Наприкінці 2018 р. Міністерство фінансів затвердило Методичні рекомендації зі складання цієї форми Звіту [13]. Отже, нормативне підгрунтя для складання Звіту є, але питань щодо його складання не стало менше. Фахівці звикли до затверджених форм звітів, але при складанні цієї форми мова йде про креативність, яку необхідно проявити при його складанні. На думку автора, ефективність складання звіту про управління напряму залежить від вимог щодо цієї форми, оскільки, саме забезпечення вимог можливе при належній організації процесу формування звітності на основі дотримання методики та порядку визначених в обліковій політиці підприємства процедур. Вимоги до цієї форми можна умовно поділити на дві групи: традиційні, а саме: обов'язковістю подання, можливістю порівнювати показники, простотою та ясністю, доречністю інформації, достовірністю та повнотою, доступністю та гласністю, раціональністю, економічністю та своєчасністю подання; так і досить специфічних, як для 
звітності вимог. Мова йде, наприклад, про візуальність звіту (візуалізація - це найкращий спосіб пояснити складні поняття. Слід використовувати інфографіку, ілюстрації, фото і відео і т.п. ), він повинен бути комунікативним ( тобто розповідати про успіхи підприємства та його перспективи, описати ризики, які існують у бізнесі, і пояснити, за рахунок чого підприємство здатне 3 ними впоратися. Звіт про управління може стати містком, що зміцнює лояльність до бренду підприємства). Серед вимог до звіту слід назвати і те, що він повинен довести свою надійність, мається на увазі зробити звіт з прицілом на партнерів, теперішніх та майбутніх, щоб продемонструвати їм надійність вашої компанії та стійкий тренд на зростання. I ще одна важлива вимога звіту, це спрямованість його на конкретну цільову аудиторію. У ньому читачі повинні знайти чіткі відповіді на питання стосовно підприємства, які їх хвилюють. Виконання усіх цих вимог дасть можливість зробити звіт про управління багатофункціональним маркетинговим інструментом, отримати довгостроковий ефект у вигляді зростання клієнтів та довіри суспільства. Традиційно, складання будь-якої форми звітності це процес, який включає два етапи: складання та подання. Складання звіту про управління слід починати із розподілу робіт між виконавцями, визначення складу робіт, які потребують виконання, до початку складання звітності та підготовці робочих таблиць для накопичення відповідної інформації розробка робочих інструкцій зі складання звітності; проведення інструктивних нарад зі складання звіту. Тобто, можна говорити про підготовчий етап. Зважено до розгляду етапів складання звітності підійшла Бондар Т.А., яка при складанні цієї форми звітності визначає наступні етапи: підготовчий; збір та перевірка інформації; написання та оформлення звіту; аудит і верифікація звіту; публікація звіту та забезпечення його доступності для зацікавлених сторін [1]. Аналізуючи ці етапи, автор вважає за потрібне під час підготовчого етапу розробляти робочі таблиці, у яких буде накопичуватись масив інформації, який стане у нагоді при формуванні звіту. Слід зазначити, що структура цих таблиць та їх наповнення буде залежати від виду діяльності підприємства та від того, до якої класифікаційної групи (у відповідності до Закону України «Про бухгалтерський облік і фінансову звітність») воно відноситься, уніфікація цього звіту не передбачена нормативними актами. Структурно звіт необхідно поділити на окремі розділи для зручності користувачів. Робочі таблиці слід підпорядковувати саме цим розділам. Якщо компанія колись описувала, наприклад, іiі вплив на навколишнє середовище, немає потреби дублювати цю інформацію, можна у відповідному розділі посилатися на раніше підготовлені матеріали. Це значно спрощує його підготовку складання звіту. Питання, хто буде відповідати за складання цієї форми, залишається відкритим, оскільки законодавчо це не визначено. Ураховуючи, що підприємства про цю форму взнали з Закону України № 2141, можна припустити, що складати його повинні представники бухгалтерської служби. Ураховуючи значну кількість інформації, яку слід відображати у звіті, доцільно розділити його складання між фахівцями відповідних служб. На думку автора, узагальнювати всю зібрану інформацію може бухгалтер-аналітик, 
який відповідає за ведення управлінського обліку на підприємстві. По - перше, тому що саме він має усі аналітичні матеріали щодо стану розвитку підприємства, і йому як найлегше буде роботи прогнози щодо майбутнього підприємства. По - друге: узагальнення інформації однією особою забезпечить досягнення вищого рівня інформативності та зрозумілості цієї форми. Не до кінця вирішеним на сьогодні залишається питання кому подавати цю форму звіту. Нормативно записано, що ¥іі необхідно оприлюднювати разом 3 фінансовою звітністю не пізніше ніж до 30 квітня року, що настає за звітним періодом. Ця норма стосується підприємств, що становлять суспільний інтерес (крім великих підприємств, які не є емітентами цінних паперів), публічні акціонерні товариства, суб'єкти природних монополій на загальнодержавному ринку та суб'єкти господарювання, які провадять діяльність у видобувних галузях, мають оприлюднювати фінзвітність на веб-сайті [12]. ДФС та Держстат не претендують на цю форму, а це означає, що наші фахівці, які звикли до чіткої регламентації звітності та покарань за неправдивість викладеної інформації, можуть відноситись невідповідально до складання цього звіту. А значить, не буде виконана мета заради якої складається звіт про управління. Анна Хомюк щодо подання цієї форми вказує на наступне: «Звіт не усюди йде тандемом із фінзвітністю. Ми би трактували цю зв'язку навпаки: фінзвітність має подаватися всюди, де просять Звіт, оскільки вона допомагає правильно трактувати показники Звіту про управління» [14]. Ми вважаємо, що ця думка $\epsilon$ найбільш слушною у період невизначеності законодавчої бази щодо цього питання.

Висновки і перспективи подальших досліджень. Підводячи підсумки слід відзначити, що організація складання звіту про управління регламентується низкою нормативних документів, у яких визначаються приблизна структура форми, терміни подання тощо. Цими документами визначено, що звіт не відноситься до фінансової звітності. Підготовка та складання звіту має свої етапи, що зумовлені складністю виконуваних робіт. Виконання вимог, що ставляться перед цією формою, забезпечать отримання підприємством довгострокового ефекту у вигляді зростання клієнтів та довіри суспільства. У подальшому слід звернути увагу на західні аналоги цієї форми, для запозичення відповідного досвіду щодо ії складання.

\section{Перелік посилань}

1. Бондар Т. А. Звіт про управління: етапи складання. Сучасні тендениії розвитку обліку, оподаткування, аналізу і аудиту. К.: КНЕУ, 2017. С. 115-117.

2. Безверхий К. В., Пантєлєєв В. П.. Консолідований звіт про управління. Новації управлінської практики звітування: сайт URL: file://C:/Users/Pavel/Downloads/128-Article\%20Text-251-1-10-20180406.pdf (дата звернення: 08.10.2019). 3. Хомюк А. «I чужо навчайтесь, й свого не цурайтесь...», або як скласти звіт про управління: сайт URL: https://ibuhgalter.net/material/618/12465 (дата звернення: 08.10.2019). 
4. Безверхий К. В. Порівняння елементів структури інтегрованої звітності та звіту про управління: сайт URL: file:///C:/Users/Pavel/Downloads/169Article\%20Text-312-1-10-20190315.pdf (дата звернення: 08.10.2019).

5. Байкар Ю. П. Нефінансова звітність підприємств та етапи іiі формування:сайтURL:http://nbuv.gov.ua/UJRN/Vonu_econ_2015_20_1\%281\%29_ (дата звернення: 11.10.2019).

6.Мацьків Р. Т. Нефінансова звітність - складова управління соціальною відповідальністю підприємств нафтогазового комплексу: сайт URL: http://nbuv.gov.ua/UJRN/efek_2015_3_60 (дата звернення: 09.10.2019).

7.Жураковська I. В. Майбутні події як об’єкт управлінського та фінансового обліку. Розвиток обліку, аналізу і аудиту суб'єктів суспільного інтересу. м. Житомир. Житомир: Видавець О. О. Свенок, 2017. С. 52-54.

8. Рогозний C., Озеран А.. Звіт про управління: історичні й законодавчі передумови складання: сайт URL: https://www.golovbukh.ua/article/7447-zvt-proupravlnnya-neviznacheniy-ne-zovsm-buhgalterskiy (дата звернення: 14.10.2019).

9. Онищенко В.. Звіт про управління - не визначений і не зовсім бухгалтерський: сайт URL: https://www.golovbukh.ua/article/7447-zvt-proupravlnnya-neviznacheniy-ne-zovsm-buhgalterskiy.

10. Озеран А. Звіт керівництва vs звіт про управління: проблеми відповідності закону про бухгалтерський облік та світової практики: сайт URL: https://zakon.help/files/article/9627/\%D0\%97\%D0\%B2\%D1\%96\%D120\%D08F.pdf (дата звернення 16.10.2019).

11. Калітенко Д. О Таксономія та аналітична інтерпретація фінансової звітності підприємств суспільного інтересу: сайт URL: http://www.visnykeconom.uzhnu.uz.ua/archive/19_2_2018ua/5.pdf (дата звернення: 16.10.2019).

12. Закон України "Про внесення змін до Закону України «Про бухгалтерський облік та фінансову звітність в Україні» щодо удосконалення деяких положень” від 05.10 .2017 p. № 2164-VIII: сайт URL http://zakon0.rada.gov.ua/ laws/show/2164-19(дата звернення: 16.10.2019).

13. Методичні рекомендації зі складання звіту про управління затверджено. Наказ Міністерства фінансів України 07.12.2018 № 982: сайт URL: https://zakon.rada.gov.ua/rada/show/v0982201-18 (дата звернення: 06.10.2019).

14. Хомюк А. Звіт про управління: пристрасті вирують: сайт URL: https://ibuhgalter.net/articles/194 (дата звернення: 06.10.2019).

\section{References}

1. Bondar T. A (2017), Zvit is about a management: drafting stages [Zvit pro upravlinnya: etapy` skladannya. Suchasni tendenciyi rozvy`tku obliku, opodatkuvannya, analizu i audy`tu], Modern progress of account, taxation, analysis and audit trends, K.: KNEU, P. 115-117.

2. Bezverkhiy K. In., Panteleev In. P. The consolidated report is on a management. Innovations of administrative practice of accounting [Konsolidovany $j$ zvit pro upravlinnya. Novaciyi upravlins `koyi prakty`ky`zvituvannya], available at: 
file://C:/Users/Pavel/Downloads/128-Article\%20Text-251-1-10-20180406.pdf (last accessed 08.10.2019).

3. Khomyuk And. «And stranger study, and it not curaytes'.», or how to report about a management [«I chuzho navchajtes`, j svogo ne czurajtes'...», abo yak sklasty` zvit pro upravlinnya], available at: https://ibuhgalter.net/material/618/12465 (last accessed 08.10.2019)

4. Bezverkhiy K. V. Porivnyannya elements of structure of the computerintegrated accounting and report on a management [Porivnyannya elementiv struktury integrovanoyi zvitnosti ta zvitu pro upravlinnya], available at: file://C:/Users/Pavel/Downloads/169-Article\%20Text-312-1-10-20190315.pdf (last accessed 08.10.2019)

5. Baykar Yu. P. The Unfinancial accounting of enterprises and stages of its forming [Nefinansova zvitnist` pidpry`yemstv ta etapy` yiyi formuvannya], available at: http://nbuv.gov.ua/UJRN/Vonu_econ_2015_20_1\%281\%29_14 (last accessed 11.10.2019).

6. Maczkiv R. T. The Unfinancial accounting is a constituent of management of enterprises of oil and gas complex social responsibility [Nefinansova zvitnist' skladova upravlinnya social noyu vidpovidal'nistyu pidpry`yemstv naftogazovogo kompleksu], available at: http://nbuv.gov.ua/UJRN/efek_2015_3_60 (last accessed 09.10.2019).

7. Zhurakovska I. V. The Future events as object of administrative and financial account. Development of account, analysis and audit of subjects of public interest [Majbutni podiyi yak ob'yekt upravlins 'kogo ta finansovogo obliku. Rozvy 'tok obliku, analizu i audy`tu sub'yektiv suspil’nogo interesu], Zhytomyr: Publisher O. O. Yevenok, 2017. P. 52-54.

8. Rogoznyj S., Ozeran A. Report on a management: historical and legislative pre-conditions of stowage [Zvit pro upravlinnya: istory`chni $\mathrm{j}$ zakonodavchi peredumovy` skladannya], available at: https://www.golovbukh.ua/article/7447-zvtpro-upravlnnya-neviznacheniy-ne-zovsm-buhgalterskiy (last accessed 14.10.2019).

9. Onyshhenko V. Report on a management - not certain and not quite bookkeeping [Zvit pro upravlinnya - ne vy`znacheny`j i ne zovsim buxgalters`ky`j], available at: https://www.golovbukh.ua/article/7447-zvt-pro-upravlnnyaneviznacheniy-ne-zovsm-buhgalterskiy_last accessed_16.10.2019).

10. Ozeran A. Report of guidance vs report on a management: problems of accordance of law on a record-keeping and world practice [Zvit kerivny'cztva vs zvit pro upravlinnya: problemy` vidpovidnosti zakonu pro buxgalters`ky`j oblik ta svitovoyi prakty'ky`], available at: https:// https://zakon.help/files/article/9627/\%D0\%97\%D0\%B2\%D1\%96\%D120\%D08F.pdf (last accessed 16.10.2019)

11. Kalitenko D. O . Oh Taxonomy and analytical interpretation of the financial reporting of enterprises of public interest [Taksonomiya ta anality'chna interpretaciya finansovoyi zvitnosti pidpry`yemstv suspil 'nogo interesu], available at: http://www.visnyk-econom.uzhnu.uz.ua/archive/19_2_2018ua/5.pdf (last accessed 16.10.2019). 
12. Law of Ukraine "On making alteration in Law of Ukraine "On a recordkeeping and financial reporting in Ukraine" in relation to the improvement of some positions" from 05.10.2017 № 2164 - (-000-2-) .[ Zakon Ukrayiny' "Pro vnesennya zmin do Zakonu Ukrayiny` «Pro buxgalters`ky`j oblik ta finansovu zvitnist` v Ukrayini» shhodo udoskonalennya deyaky`x polozhen'” vid 05.10.2017 r. \# 2164VIII], available at: http://zakon0.rada.gov.ua/ laws/show/2164-19\#05 (last accessed 16.10.2019).

13. Methodical recommendations from the stowage of report on a management are ratified. Order of Ministry of finance of Ukraine 07.12.2018 № 982 [Metody`chni rekomendaciyi zi skladannya zvitu pro upravlinnya zatverdzheno. Nakaz Ministerstva finansiv Ukrayiny 07.12.2018 \# 982], available at: https://zakon.rada.gov.ua/rada/show/v0982201-18 (date of appeal: 06.10.2019). [: sajt URL: https://zakon.rada.gov.ua/rada/show/v0982201-18 (last accessed 06.10.2019).

14. Xomyuk A. Report on a management: passions seethe [Zvit pro upravlinnya: pry`strasti vy`ruyut'], available at: https://ibuhgalter.net/articles/194 (last accessed 06.10.2019).

\section{РЕФЕРАТИ РЕФЕРАТЫ ABSTRACTS}

\section{УДК 657.37; JEL Classification: M41}

КОВАЛЬОВА Т.В. ОРГАНІЗАЦІЙНІ АСПЕКТИ ФОРМУВАННЯ ЗВІТУ ПРО УПРАВЛІННЯ

Метою дослідження $є$ інформаційна репрезентація певних моментів організації складання Звіту про управління задля забезпечення користувачів достовірною інформацією. Методика дослідження: для досягнення поставленої мети у роботі були використані загальнонаукові і спеціальні методи і прийоми дослідження: теоретичного узагальнення, аналізу і синтезу; системного і комплексного підходу; монографічний; абстрактно-логічний. Результати дослідження: результатом наукової роботи $\epsilon$ теоретичне узагальнення і розробка шляхів удосконалення організації формування звіту про управління. Це документ, в якому компанія розповідає про свої поточні справи та плани на майбутнє. Звіт повинен містити як фінансову, так i нефінансову інформацію, яка описує, в якому стані знаходиться підприємство та розкриває ризики для його діяльності. Ураховуючи те, що форма звіту про управління поки законодавчо не визначена, виникають певні питання щодо організації його складання. Дослідження точок зору науковців та бухгалтерської спільноти дали можливість нам висловити свою точку зору на це питання і запропонувати варіанти вирішення питань щодо організації його складання. У зв'язку з цим у роботі охарактеризовані вимоги до цієї форми звіту. Доведено, що знаючи вимоги, які висуваються до звіту, можна забезпечити ефективну організацію його складання. Наукова новизна: полягає в комплексному дослідженні проблем щодо організації складання звіту про управління. Підходи до проблемних моментів організації складання цієї форми в частині окреслених вимог дадуть змогу підприємствам зробити звіт про управління 
багатофункціональним маркетинговим інструментом, отримати довгостроковий ефект у вигляді зростання клієнтів та довіри суспільства. Практична знацущість полягає в тому, що дотримання підприємствами запропонованих положень забезпечить достовірність звітної інформації та сприятиме зміцненню довіри користувачів інформації. Ключові слова: звіт; підприємство; організація; управління; фінансова звітність; етапи; інформація; користувачі.

\section{УДК 657.37; JEL Classification: M41}

\section{КОВАЛЕВА Т.В. ОРГАНИЗАЦИОННЫЕ АСПЕКТЫ} ФОРМИРОВАНИЯ ОТЧЕТА ОБ УПРАВЛЕНИИ

Целью исследования является информационная репрезентация определенных моментов организации составления Отчета об управлении, который обеспечивает пользователей достоверной информацией. Методика исследования: для достижения поставленной цели в работе были использованы общенаучные и специальные методы и приемы исследования: теоретического обобщения, анализа и синтеза; системного и комплексного подхода; монографический; абстрактно-логический. Результаты исследования: результатом научной работы является теоретическое обобщение и разработка путей, которые усовершенствуют организацию формирования отчета об управлении. Это документ, в котором компания рассказывает о своих текущих делах и планах на будущее. Отчет должен содержать как финансовую, так и нефинансовую информацию, которая описывает, в каком состоянии находится компания и раскрывает риски для ее деятельности. Учитывая то, что форма отчета об управлении пока законодательно не определена, возникают определенные вопросы относительно организации его составления. Исследование точек зрения научный работников и бухгалтерского сообщества дали возможность нам высказать свою точку зрения на этот вопрос и предложить варианты решения вопросов относительно организации его составления. В связи с этим в работе охарактеризованные требования к этой форме отчета. Доказано, что зная требования, которые выдвигаются к отчету, можно обеспечить эффективную организацию его составления. Научная новизна: заключается в комплексном исследовании проблем относительно организации составления отчета об управлении. Подходы к проблемным моментам организации составления этой формы в части очерченных требований дадут возможность предприятиям сделать отчет об управлении многофункциональным маркетинговым инструментом, получить долгосрочный эффект в виде роста клиентов и доверия общества. Практическая значимость. Соблюдения предприятиями предложенных положений обеспечит достоверность отчетной информации и будет оказывать содействие укреплению доверия пользователей информации. Ключевые слова: отчет; предприятие; организация; управление; финансовая отчетность; этапы; информация; пользователи. 


\section{UDC 657.37; JEL Classification: M41}

\section{KOVALOVA T. V. ORGANIZATIONAL ASPECTS OF MANAGEMENT REPORT FORMING}

Purpose is informative representation of certain organization moments of management report forming for the sake of providing users reliable information. Methodology of research: to meet an aim during the research were used the next general scientific and special methods, skills of research: theoretical generalization, analysis and synthesis; systems and complex approach; monographic; abstractly logical. Findings: result of scientific research is theoretical generalization and development ways of improvement organization of management report preparation. A company describes current businesses situation and plans on the future in this document. A report must contain both financial and unfinancial information that describes current state of enterprise and discloses risks for its activity. Taking into account that the form of management report still is not legislatively appointed, there are some questions in relation to organization of its forming. Researching scientists points of view and book-keeping association gave an opportunity to expound our own point of view on this question and offer the variants of decision these questions concerning organization of its forming. Because of this in research were described requirements to this form of report. It was proven that knowing the requirements that were pulled out to the report, it was possible to provide effective organization of its forming. Originality: consists in complex research of problems concerning organization of management report forming. Concepts to the problem moments organization this report forming in part of outlined requirements will give an opportunity for enterprises to make the management report multifunction marketing instrument, and to get a long-term effect as an increase of clients and trust of society. Practical value. Compliance of enterprise proposed positions will provide authenticity of current information and will assist in strengthening trust of users of information. Key words: report; enterprise, organization; management; financial reporting; stages; information; users.

\section{Відомості про авторів /Сведения об авторах / About the Authors}

Ковальова Тетяна Володимирівна - кандидат економічних наук, доцент, Харківський національний автомобільно-дорожній університет, доцент кафедри обліку, оподаткування та міжнародних економічних відносин; м. Харків,Україна; ORCID: https://orcid.org/0000-0003-1250-2019; e-mail: kovaleva64@ukr.net.

Ковалева Татьяна Владимировна - кандидат экономических наук, доцент, Харьковский национальный автомобильно-дорожный университет, доцент кафедры учета, налогообложение и международных экономических отношений.

Kovalova Tetiana Volodimipovna - Candidate of Sciences (Economics), Kharkov National Automobile and Highway University, Associate Professor at the Department of account, taxation and international economic relations, Kharkiv, Ukraine. 